\title{
HENGENPELASTAJAT TYÖSSÄÄN
}

Välillä, kun mokaa töissä, ajattelee, että onneksi kukaan ei kuollut - niin riskialtista työmme ei onneksi ole. Harvemmin tulee ajatelleeksi, että joskus me pelastamme ihmisiä.

Tapasin kesällä Yhdysvaltojen kirjastoseuran puheenjohtajan Loida Garcia-Febon Helsingissä. Kiersimme yhdessä Helsingin yliopiston Kaisa-taloa ja nähdessään Pride-teemaisen American Resource Centerin kirjanäyttelyn hän ilahtui. "Meillä tällaista on nykyisin vaikeaa tehdä", hän kertoi. "Poliittinen ilmapiiri on muuttunut konservatiivisemmaksi. Jos järjestää tällaisen kirjanäyttelyn, seuraa vihaista palautetta ja uhkailua. Moni vaikutusvaltainen henkilö sanoo, ettei kirjasto saisi kannustaa ihmisiä olemaan oma itsensä, esimerkiksi kuulumaan seksuaalisen vähemmistöön. Vihainen rahoittaja saattaa vetää lahjoituksensa pois."

Elämän pelastaminen voi olla hyvin kouriintuntuvaa. Garcia-Febo kertoi, miten Yhdysvalloissa kirjastot antavat kirjastokortin omistajille bussilippuja ja mahdollistavat täten dialyysia tarvitsevien potilaiden sairaalakäynnit. Kirjastot auttavat väkivallan uhreiksi joutuneita aikuisia ja lapsia pääsemään turvakoteihin, tukevat lukemaan oppimista ja auttavat työnhaussa. Kirjastot puolustavat demokratiaa, ajattelun ja ilmaisun vapautta sekä yhteisön vastuuta yksilöistään.
Joskus kirjat pelastavat ihmisiä. Lukijat löytävät niistä tietoa, lohtua, kohtalotovereita, tukea omille ajatuksilleen ja identiteetilleen. Tuttu tietokirjailija kertoi saaneensa kiitosviestin: hänen kirjansa oli pelastanut lukijansa hengen.

Garcia-Febon presidenttikauden tunnuslause on "Kirjastot = vahvat yhteisöt. Kirjastot voimaannuttavat opiskelijoita, opettajia, tutkijoita ja kansalaisia".

Vaikka siltä ei aina kaamoksessa tunnu, mekin työllämme voimaannutamme ja välillä jopa pelastamme.

\section{$\cos$}

Vuonna 2019 sTKs:n 90-vuotissyntymäpäivää on juhlittu historiikin julkistamisella ja juhlaseminaarilla - voit lukea molemmista lisää tästä lehdestä. Kun lukee seuran historiikkia, ymmärtää miten me olemme aina olleet muutoksentekijöitä. Ei ole ollut pysähtynyttä aikaa, vaan olemme aina ennakoineet ja uudistaneet. Emme ole pelänneet uusia asioita. Maailma on muuttunut ja niin mekin.

Parhaimmillaan muutos tapahtuu luontevasti, työtä tehden, niin ettei sitä joudu erikseen miettimään. Välillä sitä pakerretaan hampaat irvessä.

Vuonna 2020 seura aloittaa uuden teknologian työryhmän. Jos haluat mu-

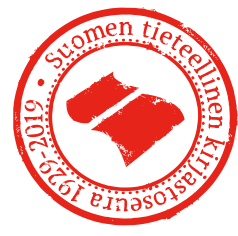


kaan, ota yhteyttä (stks@stks.fi). Mitä työryhmä alkaa tehdä? Se määrittynee ensi vuonna, työryhmän jäsenten päätöksellä ja hallituksen siunauksella.

\section{coro}

Hyvä lukija, on tullut aika kiittää. Kauteni päätoimittajana päättyy tähän lehteen ja uusi päätoimittaja valitaan pian. On ollut ilo tehdä lehteä juuri sinulle.

Haluan kiittää kaikkia, jotka ovat kirjoittaneet lehteen ja muuten edesauttaneet sen syntymistä ja uudistumista.

Erityisen suuret kiitokset kuuluvat seuraaville: STKs:n puheenjohtajat Jarmo Saarti ja Pälvi Kaiponen, sTKs:n hallituksen jäsenet vuosina 20I6-20I9, taloudenhoitaja Anne Sämpi, sihteeri Tuula Hurskainen, toimitussihteeri Minna Marjamaa, taittaja Petri Fills, pitkäaikainen päätoimittaja Päivikki Karhula, toimituskunta, Suomen tiedekustantajien liitto ja työnantajani Helsingin yliopiston kirjasto.

Pälvi Kaiponen, Tuula Ruhanen, Maria Forsman ja monet muut rakkaat kollegat - kiitos kun kannustitte minua liittymään seuraan ja sen työryhmiin. Työskentely työryhmissä ja Signumissa on ollut virkistävää ja voimaannuttavaa.

Hyvä lukijani, tämä lehti on omistettu sinulle. Toivottavasti viihdyt sen parissa.

- Johanna Labikainen 